\title{
Understanding of The Decision of Court As A Basis of Cancellation of Land Rights
}

\author{
Ayu Maulidina Larasati ${ }^{1}$ and Aprila Niravita ${ }^{2}$ \\ \{dina.ayu200@gmail.com, aprilaniravita@mail.unnes.ac.id\} \\ ${ }^{1,2}$ Faculty of Law, Universitas Negeri Semarang, Semarang Indonesia
}

\begin{abstract}
This Article aims to analyze the cancellation of land rights as a Decree of the Head of the Land Office and the Head of the Regional Office of the National Land Agency (Kanwil BPN) is done in the first two things, namely because of an error in the issuance of land rights. Second, because there is a Court Decision that must be implemented. This research is an empirical nondoctrinal/juridical research with a qualitative approach. The results showed that in the cancellation of Property Rights Number 1362 / Jabung BPN Regional Office of Central Java Province did not implement the decision, but made the Criminal Decision No. 222 / Pid.B / 2016 / PN.Smg. Jo 209 / Pid / 2016 / PT.SMG Jo 1412K / Pid / 2016 as supporting data in the cancellation study to prove an error in the registration of land rights, so that the Head of the Regional Office of the Central Java BPN can issue a decision on the cancellation of land rights without prior to the cancellation decision. from the State Administrative Court in accordance with the principle contrarious actus. The cancellation authority lies with the Central Java BPN Regional Office so that the Head of the Semarang City Land Office submits the results of the analysis to the Central Java BPN Regional Office for review, field inspection and exposure. Then the Head of the Regional Office of BPN in Central Java Province issued a decree on the cancellation of land rights number 07 / Pbt / BPN.33 / IX / 2019.
\end{abstract}

Keywords: Court Decision; Cancellation of Land Rights

\section{Introduction}

Utilization of the function of the earth and water and the natural resources contained therein is intended to achieve the greatest prosperity of the people, as stated in Article 33 paragraph 3 of the Law of the Republic of Indonesia in 1945. Land ownership is a human right of every citizen of Indonesia as regulated in the 1945 Constitution of the Republic of Indonesia, in particular Article $28 \mathrm{H}$ which states that every person has the right to have private property rights and these rights cannot be taken arbitrarily by anyone.

To protect land ownership rights by the government, a land registration system is implemented. One of the objectives of land registration as stipulated in Article 3 of Government Regulation No. 24 of 1997, is to provide legal certainty and protection to holders of registered land rights in order to easily prove themselves to be holders of the rights in question. The certificate is a strong proof of ownership of land rights, but nevertheless, everyone can be disputed about the truth of the certificate and the right to land. Regulation of the Minister of Agrarian Affairs and Spatial Planning / Head of the National Land Agency Number 11 of 2016 serves as a guideline for the Ministry of Agraria in resolving land cases. If it can be proven the untruth of a person's land rights, Cancellation of land rights as Decree of the Head of the Land Office and Head of the Regional Office of the National Land Agency is done in the first two things, namely due to administrative defects in the issuance of the certificate, either based on a request from an interested party or party that is harmed or found 
personally by the Head of the Land Office concerned. Second, due to the existence of a Court Decision which must be implemented, for example, namely the cancellation of land rights by a state administrative court on the grounds of a legal defect due to substantial errors that contradict the applicable law [1]

In the Regional Office of the National Land Agency of Central Java Province, there has been a cancellation of land rights due to administrative defects based on the existence of a criminal decision, namely on the cancellation of Property Rights Number 1362 / Jabung on behalf of Jadiaman Simbolon. On June 15, 2017, Nuning Lestari made a request for revocation of the Certificate to the Head of the Semarang City Land Office for Ownership of Property No. 1362 / Jabung located in Jabung Sub-District, Banyumanik District, Semarang City in Central Java with an area of 6849 M2 which was registered in the name Jadiaman Simbolon. Nuning makes a request for revocation of land rights by bringing evidence in the form of Criminal decision No.222 / Pid.B / 2016 / PN.Smg. Jo 209 / Pid / 2016 / PT.Smg Jo 1412 K / PID / 2016 who have permanent legal force.

Criminal case Number 222 / Pid.B / 2016 / PN.Smg Jo. No. 209 / Pid / 2016 / PT.Smg Jo. No. 1412 K / PID / 2016. with the defendant Jadiaman Simbolon, SH bin Milior Simbolon on the charge of the crime of "ordering to insert false information into an authentic deed" as provided for in article 266 paragraph (1) of the Criminal Code. The verdict on the case stated that Soaman Simbolon was proven legally and convincingly guilty of committing a crime of "ordering to insert false information into an authentic deed", for his mistake, Jadiaman Simbolon was sentenced to two years in prison.

Through the criminal verdict, it can be seen that Jadiaman Simbolon has been guilty of the indictment of article 266 paragraph (1) of the Criminal Code, so that in the Certificate of Ownership Number 1362 / the Combination on behalf of Jadiaman Simbolon there is false information contained therein.

From the explanation above, this study aims to determine the meaning of criminal decision No. 222 / Pid.B / 2016 / PN.Smg Jo. No. 209 / Pid / 2016 / PT.Smg Jo. No. 1412 K / PID / 2016 in the cancellation of Property Rights Number 1362 / Joint and the mechanism for cancellation.

Based on the background stated above, then the problem can be formulated as follows: (1) How to interpret criminal verdict No. 222 / Pid.B / 2016 / PN.Smg Jo. No. 209 / Pid / 2016 / PT.Smg Jo. No. 1412 K / PID / 2016 in the cancellation of Ownership Right Number 1362 / Combination on behalf of Jadiaman Simbolon; and (2) How is the mechanism for implementing the revocation of ownership rights number 1362 / merger on behalf of Jadiaman Simbolon.

\section{Method}

The research approach used by researchers is a qualitative approach to the type of empirical juridical research or non-doctrinal research, which is an approach by looking at something of legal reality in society. [2]

Sources of research data obtained by two types of data, namely primary data that is data collected from the first hand and processed by an organization or individual [3] and secondary data, namely among others including official documents, books, results from research in the form of reports and so on.[4]

The researcher conducts data validity using source triangulation because the triangulation is closely related to data collection techniques taken by researchers in interviewing and document data collection. Analysis of the data used in writing includes data collection, data education, data presentation, and drawing conclusions.

\section{Result and Discussion}


3.1 The meaning of criminal verdict No. 222 / Pid.B / 2016 / PN.Smg Jo. No. 209 / Pid / 2016 / PT.Smg Jo. No. 1412 K / PID / 2016 in the cancellation of Property Rights Number 1362 / Combination on behalf of Jadiaman Simbolon

Certificate of land rights is a State Administration Decree (KTUN) issued by the Ministry of Agrarian Affairs and Spatial Planning / National Land Agency which is the Office of State Administration.

In Act Number 51 of 2009 concerning the Second Amendment to Act Number 5 of 1986 concerning State Administrative Court in article 1 number 9 states that:

"State Administration Decree is a written stipulation issued by a state administration

body or official containing legal action on state administration based on applicable

legislation, which is concrete, individual, and final that results in legal consequences

for a person or legal entity. civil"

According to Article 32 of Government Regulation No. 24 of 1997 of 1997, it is explained that certificates are proof of rights that act as strong evidentiary tools regarding physical data and juridical data contained therein, as long as the physical and juridical data are in accordance with the data in measuring certificate and land book concerned.

Guaranteed legal certainty, protection, and justice for those who feel disadvantaged as a result of the KTUN against land claims are settled through the State Administrative Court (PTUN). PTUN's decision aims to provide an opportunity to take legal action against disputes arising in the field of State Administration. [5]

In-State Administrative Court, the time limit for filing a lawsuit is as stated in Article 55 of Law Number 5 of 1986 concerning State Administrative Court, which is 90 days from the issuance of KTUN, so if 90 days have passed, PTUN can no longer accept the claim. However, disputes regarding land rights certificates can in fact still be heard in the District Court.

According to Dr. Syofyan Iskandar, SH, MH, Judge of the Semarang State Administrative Court Regarding the time period of the lawsuit, the District Court adheres to the principle of axio pepertua which does not recognize the time period, but if the PTUN recognizes the time period in filing a lawsuit that is 90 days since the issuance of KTUN. Therefore, if more than 90 days have been issued, KTUN can be sued in the District Court.

The difference in the object of the case in the district court and the Administrative Court is that in the District Court the object of the case (objektum litis) in a dispute is the rights or interests of the community that are violated as a result of the issuance of a State Administration Decree whereas in a State Administrative Court the being the object of the case is the State Administrative Decree itself.

In filing a civil claim, there is a grace period for filing a lawsuit that is 5 (five) years since the issuance of the certificate, as stipulated in Article 32 paragraph (2) PP Number 24 of 19997 regarding Land Registration which reads:

"In the case of a piece of land that has been legally issued a certificate in the name of the person or legal entity who obtained the land in good faith and has actually mastered it, then the other party feels that it has no right to land that can no longer demand the implementation of that right if in time 5 (five) years since the issuance of the certificate did not file an objection in writing to the certificate holder and the Head of the Land Office concerned or did not file a lawsuit to the Court regarding land acquisition or issuance of the certificate. "

This means that if it has been more than 5 (five) years since the issuance of the certificate, it can no longer file a lawsuit. However, the existence of the grace period is not absolute as long as it can be proven that the acquisition of the land was done not in good faith.

In the case of a dispute between Nuning Lestari and Jadiaman Simbolon, the party from Nuning Lestari chose to take the criminal route to prove that Jadiaman Simbolon in obtaining his rights to 
his land committed acts that were prohibited by law. In 2016 Jadiaman Simbolon was reported to Semarang Police District by Sahid Nugroho (Nuning Lestari's biological son) on charges of falsifying an authentic deed.

In the trial, it was revealed that the sale and purchase letter dated June 23, 1993, between Jamian's heirs as the seller and Jadiaman Simbolon as the buyer used by Jadiaman Simbolon for the certification process was an illegal sale and purchase letter because Jamian's heirs had never sold the land to Jadiaman Simbolon.

The Semarang District Court issued Decision Number 222 / Pid.B / 2016 / PN.Smg. The symbol of the Jadiaman Simbolon fulfills the charge of violating article 266 paragraph (1) of the Indonesian Criminal Code which consists of:

1) Whoever

"Whosoever" is meant as a legal subject supporting rights and obligations, and from the results of the examination of the identity of the defendant at the trial, the legal subject is the defendant, thus the element of whoever has been fulfilled;

2) Asking to insert false information into an authentic deed regarding something whose truth must be stated by the deed

what is meant by "authentic deed" is a letter made by a public office according to the forms and conditions specified in the law and or a letter that must be signed, must be made intentionally and must be used by people for the purposes for whom the letter was made.

Authentic deed referred to in a quo case includes:

- $\quad$ SHM Number 01362 on behalf of the Defendant

- $\quad$ Decree Number: 4-XC-2005 dated July 14, 2005, canceling SHM No. 444 and SHM No. 445

Thus the element "Telling to insert false information into an authentic deed concerning something whose truth must be stated by the deed" has been fulfilled.

3) With the intention to use or order others to use the deed as if the statement is in accordance with the truth;

Upon request of the Defendant's Certificate Then the Semarang City Land Office on October 29, 2007 issued SHM 01362 / Jabung on behalf of the Defendant

Thus the element "With the intention to use or order others to use the deed as if the statement is in accordance with the truth" has been fulfilled.

4) If its use can cause harm;

- As a result of the defendant's actions, the witness Nuning Lestari suffered a loss, namely the loss of the right to control and use the land of approximately $3418 \mathrm{~m} 2$ owned by the witness Nuning Lestari in accordance with SHM 445 in Ex. Jabung Kec. Banyumanik, Semarang City

Thus the element "If its use can cause harm" has been fulfilled.

Criminal Decision No.222 / Pid.B / 2016 / PN.Smg dated June 21, 2016, the verdicts include:

1.Stating the Defendant: JADIAMAN SIMBOLON, SH Bin (alm) BILLION OF SYMBOLON has been legally proven and convicted of committing a criminal act of "ordering the insertion of false information into an authentic deed"

2.Convicting the Defendant is therefore imprisoned for 1 (one) year and 6 (six) months;

3.Order evidence:

1 (one) bundle of land book along with the mark of SHM No. 1362 / Ex. The merger on behalf of JADIAMAN SIMBOLON was returned to BPN Semarang through witness ENI SETYOSUSILOWATI, SH. MH.

Then on the decision, the legal counsel from Jadiaman Simbolon filed an appeal, which resulted in decision number No. 209 / Pid / 2016 / PT.SMG dated September 1, 2016, whose decisions include: 
1. Stating the Defendant: JADIAMAN SIMBOLON, SH Bin (alm) BILLION OF SYMBOLON has been legally proven and convicted of committing a criminal act of "ordering the insertion of false information into an authentic deed"

2. Convict the Defendant, therefore, by imprisonment for 2 (two) years;

3. Order evidence:

1 (one) bundle of land book along with the mark of SHM No. 1362 / Ex. The merger on behalf of JADIAMAN SIMBOLON was returned to BPN Semarang through witness ENI SETYOSUSILOWATI, SH. MH

Jadiaman Simbolon as the defendant in the case, submitted an appeal which resulted in No. 1412 K / PID / 2016 dated January 6, 2017 whose decisions include:

Judge:

Refuse the cassation request from the Cassation / Defendant.

So, in the case of the crime, Jadiaman Simbolon was proven guilty of article 266 of the Criminal Code and received a sentence of two years in prison. According to Abdul Wahib, SH, MH, a Judge at the Semarang District Court in his interview on February 20, 2020, stated that the sentence of the criminal decision had no effect on whether a certificate was canceled or not, because the criminal entered into the realm of public law governing relations between people and the state, not regulate the rights of individuals. Therefore, in a criminal decision, even if it is proven that there is an interest or right of someone else who has been violated by the issuance of a certificate, the Criminal Court cannot decide to declare the certificate null and void. According to Dr. Syofyan Iskandar, SH, MH, Judge of the Semarang State Administrative Court, in canceling land rights there are two things, namely, there is a cancellation based on the contrarious actus principle that can be done by the official who issues the KTUN or officials at the level above it and the certificate revocation in the implementation of the court decision legally binding.

According to Philipus M. Hadjon and Tatiek Sri Djatmiati, the principle of contrarious actus in state administrative law is the principle that states that a TUN Agency or Officer who issues a TUN Decree by itself is also authorized to cancel it. This principle applies even though in the TUN decision there is no common safety clause. If in the future there turns out to be a mistake or error, then this decision will be reviewed (Hadjon and Djatmiati, 2009: 78).[6] So, even though through criminal ruling No. 222 / Pid.B / 2016 / PN.Smg Jo. No. 209 / Pid / 2016 / PT.SMG Jo. No. 1412 K / PID / 2016 it is known that Jadiaman Simbolon has been legally and convincingly guilty of committing a crime as contained in article 266 paragraph (1) of the Criminal Code, to cancel the right to his land, it is necessary to request a revocation of land rights to the Ministry of Agrarian Affairs and Spatial Planning / National Land Agency as the body that issues certificates of land rights. Therefore, in the cancellation of Property Rights Number 1362 / Joint Office of the Regional Office of BPN Central Java Province does not implement the decision, but makes the Criminal Decision No. 222 / Pid.B / 2016 / PN.Smg. Jo 209 / Pid / 2016 / PT.SMG Jo 1412K / Pid / 2016 as study material for cancellation to prove mistakes in the issuance of property rights Number 1362 in the name of Jadiaman Simbolon.

\subsection{The mechanism for implementing the revocation of ownership rights number 1362 / merger on behalf of Jadiaman Simbolon}

Article 19 of the BAL stipulates that in order to guarantee legal certainty by the government land registration is carried out throughout the territory of the Republic of Indonesia according to the provisions regulated by government regulations. The purpose of land registration as contained in Government Regulation No. 24 of 1997 in addition to providing legal certainty, it can also provide protection to holders of rights over a parcel of land. To provide legal certainty and legal protection, the relevant rights holders are given certificates of land rights.

Cancellation of land rights as Decree of the Head of the Land Office and Head of the Regional Office of the National Land Agency is done in the first two things, namely due to administrative defects in the issuance of the certificate, either based on a request from an interested party or party 
that is harmed or found personally by the Head of the Land Office concerned. Secondly, due to the existence of a Court Decision which must be implemented, for example, namely the cancellation of land rights by a state administrative court on the grounds of a judicial defect due to substantial errors that contradict the applicable law.

Cancellation of land rights without a court decision is regulated in Regulation of the Head of Land Affairs Agency of the Republic of Indonesia Number 3 of 2011 concerning Management of Study and Handling of Land Cases in conjunction with Regulation of the Minister of Agrarian Affairs and Spatial Planning / National Land Agency Number 11 of 2016 concerning Settlement of Land Cases Referring to article 4 jo article 24 Regulation of the Minister of Agrarian Affairs and Spatial Planning / National Land Agency Number 11 of 2016, the authority of the Ministry of ATR / BPN takes decisions such as the decision to revoke land rights, the decision to revoke a certificate, without prior court ruling is only on land disputes and land conflicts, i.e. land cases whose settlement does not go through a judicial institution.

In Cancellation of Ownership Number 1362 / Merger on behalf of Jadiaman Simbolon, the Office of the Agrarian Region and Spatial Planning / National Defense Agency of Central Java Province guided by the Regulation of the Minister of Agrarian Affairs and Spatial Planning / Head of the National Land Agency (Permen ATR / Perkaban) Number 11 of 2016 concerning settlement of land cases. The settlement flow is as follows:

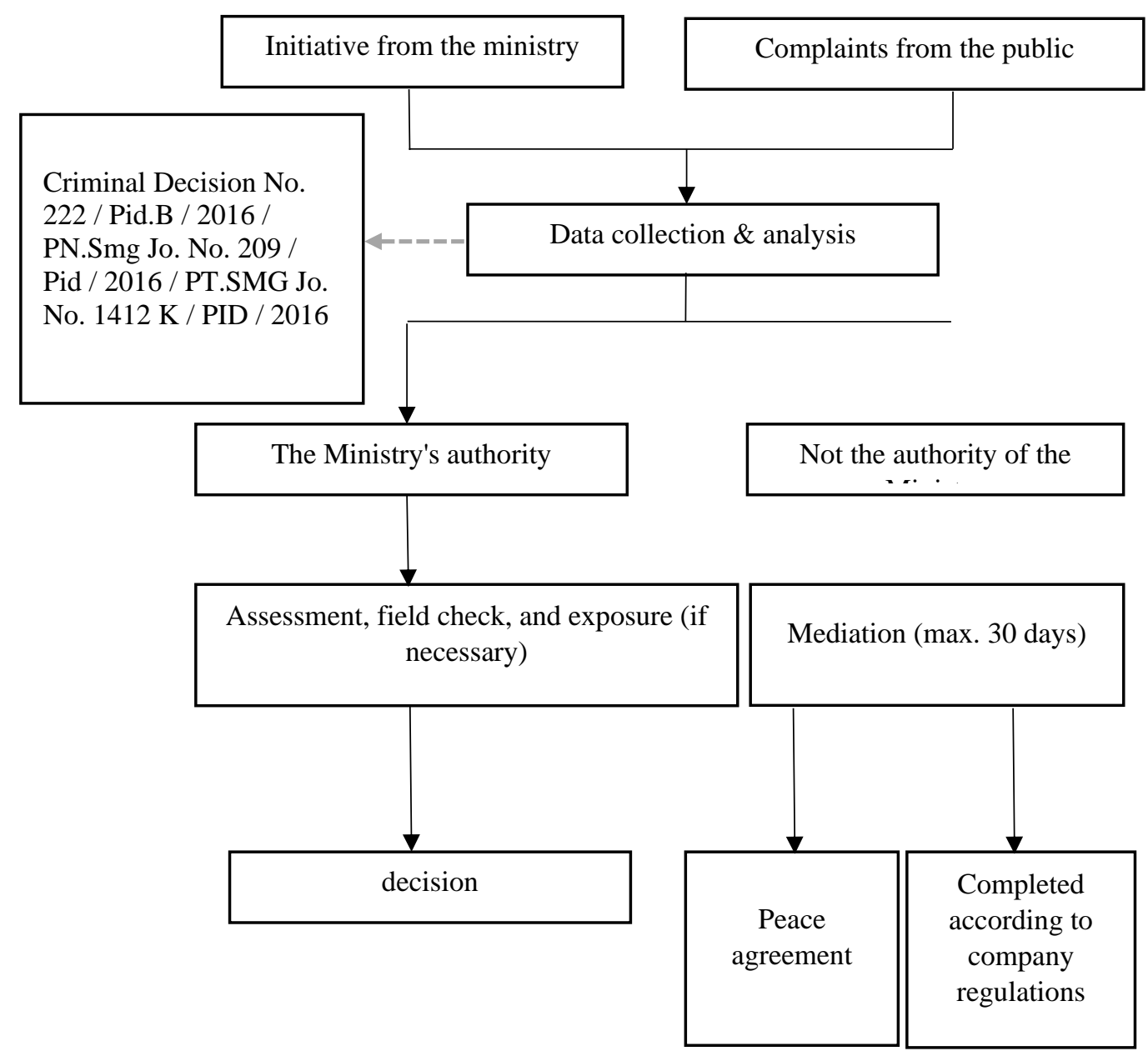




\section{fig 4.2 Settlement of land cases}

The authority to cancel ownership rights number 1362 / merger belongs to the Regional Office of the National Land Agency of Central Java Province because ownership rights number 1362 / merger on behalf of Jadiaman Simbolon is issued by the Semarang City Land Office. This is in accordance with article 26 paragraph (2) of the Agrarian Regulation and Spatial Planning / Head of the National Land Agency Number 11 of 2016, namely:

"(2) the authority to cancel as referred to in paragraph (1) consists of:

a.

inister, for the granting of rights whose decisions are debited by the Minister or Head of Regional Office of BPN, and Disputes or Conflicts with certain characteristics as referred to in article 13 paragraph (3);

b. Head of Regional Office of BPN, for the granting of rights whose interests are issued by the Head of the Land Office. "

Based on the results of an analysis conducted by the Regional Office of the Central Java National Land Agency towards Criminal Decision No. 222 / Pid.B / 2016 / PN.Smg Jo. No. 209 / Pid / 2016 / PT.SMG Jo. No. 1412 K / PID / 2016, in the issuance of Hak Milik No. 1362 / Jabung on behalf of Jadiaman Simbolon, it contains procedural errors / administrative defects.

The category of administrative disability as stated in article 11 paragraph (3) of Agrarian Regulation Number 11 Year 2016 namely:

a. Errors in procedures in measuring, mapping and / or broad calculations;

b. Errors in procedures in the process of registering affirmations and / or recognition of rights to ex-adat land;

c. Errors in procedures in the process of determining and / or registering land rights;

d. Incorrect procedure in the process of determining abandoned land;

e. Overlapping of rights or certificates of land rights where one of the basis of rights is clearly an error;

f. Errors in procedures in the process of maintaining land registration data;

g. Incorrect procedure in the process of issuing a replacement certificate;

h. Error in providing information on land data;

i. Incorrect procedures in the process of granting permits;

j. Misuse of space use; or

k. Other errors in the application of legislation.

The administrative defect in question is a procedural error contained in Article 11 paragraph (3) point $\mathrm{H}$, namely an error in providing land data information.

After the dispute resolution has been carried out as referred to in Article 24 of ATR Regulation Number 11 of 2016, the Head of Regional Office of ATR / BPN of Central Java Province or the Minister shall resolve it by:

a. Decision of Cancellation of Land Rights;

b. Certificate Cancellation Decision;

c. Decision of Changes to Data on Certificates, Measurement Letters, Land Books and / or other Public Lists; or

d. Notification that there are administrative errors

In resolving the dispute between Nuning and Jadiaman Simbolon, the Head of Regional Office of ATR / BPN of Central Java Province issued a Decree on Cancellation of Certificate Number 07 / Pbt / BPN.33 / IX / 2019. After the proof of ownership is canceled, the status of the land returns to its original state of being Yasan land with C No. 173 P. 35 K1. D.II.

Cancellation of certificate does not mean to eliminate/give rise to land rights or other civil rights to the parties in accordance with Article 26 of ATR Regulation Number 11 of 2016, namely: 
Therefore, in order to regain land rights, Nuning Lestari must register the land in accordance with applicable regulations.

\section{Conclusion}

From the results of the study, it can be concluded that the Ministry of Agrarian Affairs and Spatial Planning / National Land Agency can cancel the right to land without a court ruling which explicitly states that it is canceled if the product issued contains an error in accordance with the principle of contrarious actus. In canceling the Right of Ownership Number 1362 / the Joint Office of the Regional Office of BPN in Central Java Province did not implement the decision, but made the Criminal Decision No. 222 / Pid.B / 2016 / PN.Smg. Jo 209 / Pid / 2016 / PT.SMG Jo 1412K / Pid / 2016 as supporting data in the cancellation study to prove the existence of administrative defects in the issuance of the Certificate. Cancellation of ownership right of 1362 / Jabung without being preceded by a court decision is appropriate to be carried out to guarantee legal certainty. Implementation of Cancellation of Ownership Number 1362 / Combination on behalf of Jadiaman Simbolon is conducted by referring to Permen ATR / BPN Number 11 Year 2016 concerning the Settlement of Land cases. The Semarang City Land Office responds to the cancellation request letter from Nuning Lestari number 141 / LKBH-SF / VIII / 2018 on 1 August 2018 by conducting data collection and analysis. The authority to revoke the Property Right Number 1362 / Jabung belongs to the Regional Office of the Central Java BPN Province so that the Head of the Semarang City Land Office submits the results of his analysis to the Regional Office of the Central Java Province BPN for review, field inspection and exposure. From the results of the field assessment and inspection, it is known that in the issuance of SHM Number 01362 / Jabung on behalf of Jadiaman Simbolon there are administrative defects. For this matter, The Head of the BPN Regional Office of Central Java Province issued a decree number 07 / Pbt / BPN.33 / IX / 2019 concerning the cancellation of Property Rights Number 01362 / Jabung on behalf of Jadiaman Simbolon. The decision to revoke land rights does not cause other civil rights, so to get his rights back, Nuning Lestari must register his land again in accordance with applicable regulations.

Based on the conclusions above in accordance with the problem under study, the advice that can be given by the author is the Regional Office of the Ministry of Agrarian Affairs and Spatial Planning / National Land Agency of Central Java and Semarang City Land Office is expected to always pay attention to the General Principles of Good Governance (AAUPB) in issuing a decision to revoke land rights so as to minimize future disputes. The Semarang City Land Office is expected to be more careful in issuing land rights certificates regarding the truth of the rights and information provided by the applicant for land rights certificates by gathering facts of the situation that occurred at the time of the certificate issuance by first checking and verifying their validity and eligibility.

\section{References}

[1] Setiawan, Y. 2010. Cancellation of Land Rights Certificate by the State Administrative Court for reasons of juridical defects of the substantive aspects. Journal of Law Pro Justitia 28 (1): 91 102.

[2] Moleong, Lexy J. 2010. Qualitative Research Methodology. Bandung: Teen Rosdakarya

[3] Abdurrahman, Muslan. 2009. Sociology and Legal Research Methods. Malang: UMM Press.

[4] Amiruddin and Zainal A. 2014. Introduction to Legal Research Methods. Jakarta: PT. Grafindo Persada.

[5] Hadjon, Philipus M. 1987. Protection of the People for the People in Indonesia. Surabaya: PT. Foster Science.

[6] Mintaraningrum, Y. 2015. Aspects of Legal Certainty in Issuance of Land Rights Certificates (Analysis of Semarang State Administration Decree Number 24 / G / TUN / 2000 / PTUN.Smg). Repertorium Journal. 2 (2): 105 - 116. 
Laws and regulations:

The 1945 Constitution of the State of the Republic of Indonesia.

Law Number 5 of 1960 concerning Basic Regulations on Agrarian Principles.

Law Number 5 of 1986 concerning the State Administrative Court.

Government Regulation Number 24 of 1997 concerning Land Registration.

Regulation of the Minister of Agrarian Affairs and Spatial Planning / Head of the National Land Agency of the Republic of Indonesia Number 11 of 2016 concerning the Settlement of Land Cases.

Regulation of the Minister of Agrarian Affairs / Head of National Land Agency Number 3 of 1997 concerning Provisions for Implementing Regulation Number 24 of 1997 concerning Land Registration. 